\title{
Response of finisher broiler birds fed graded levels of yam peel meal as an energy source in maize-based diet \\ ${ }^{1}$ Ukonu, E. C., ${ }^{3}$ Ohanaka, A. U. C., ${ }^{1}$ Uzegbu, H. O., *Onunkwo, ${ }^{4}$ D. N., ${ }^{1}$ Oduehie, T. C., ${ }^{2}$ Obih, T. K. and ${ }^{2}$ Ekenyem, B. U. \\ ${ }^{I}$ National Agricultural Extension Research and Laison Service, Ahmadu Bello University Zaria, Nigeria. \\ ${ }^{2}$ Department of Animal Science and Fisheries, Imo state University P.M.B 2000, Owerri Nigeria. \\ ${ }^{3}$ Department of Animal Science and Technology, Federal University of Technology P.M.B 1526, Owerri, Department of Animal Nutrition and Forage Science,

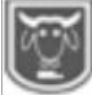 Michael Okpara University of Agriculture, Umudike, Abia State, Nigeria \\ Abstract *Corresponding email: donunkwo1@gmail.com., +2348033388622
}

The aim of this experiment is to determine the response of finisher broiler birds to graded levels of yam peel meal as an energy source to place of maize. One hundred and twenty four weeks old Marshal broiler birds were used in a 28 day feeding trial to evaluate the growth performance of the broilers. The birds were assigned into four treatment groups of 30 birds each, which were further replicated in triplicate of 10 birds per replicate in a completely randomized design (CRD). Four experimental diets containing 0, 5, 10 and 15\% inclusion of YPM were formulated and offered to birds during the study. At the end of the experiment, results obtained showed no treatment effect $(p>0.05)$ in growth performance. Birds on YPM based diets recorded similar growth performance with the control suggesting that YPM had positive effect on the experimental birds.

Keywords: Yam peel meal, finisher broiler, feed cost.

\section{Introduction}

Great emphasis has continued to be placed on research into the use of alternative feedstuff as energy sources of feed for poultry and other livestock. This is sequel to the increasing price of conventional energy sources such as maize, guinea corn, etc for livestock and poultry production (Ojewola and Annah, 2006). The resultant effect of this is shortage in animal protein and high cost of poultry production and hence poor animal protein intake among Nigerians (Akinmutimi, 2004). The average Nigerian consumes only $3.3 \mathrm{~g}$ of animal protein per person per day which is far below the FAO (2000) recommended value of $34 \mathrm{~g}$. The low level of animal protein intake by Nigerian has generated concern as it affects both physical and mental development of Nigerian youths and labour force
(Akinmutimi, 2004). One way of solving this problem is by focusing on production of animals with high rate of production and growth. One of such animals is poultry (Ezieshi et al., 2004). It is the quickest source of meat and it matures very quickly when compared to other livestock. Poultry is free from the various social, religious taboos and economic constraints which affects the commercial production of livestock. They are also characterized by low capital requirement and quick returns (Obioha, 1992). Feed accounts for between $70-80 \%$ of the total cost of production in Nigeria. This is as a result of the fact that the conventional energy sources that contributes a high percentage of the feed is being competed for by man, livestock and industries. To solve this problem there is need to search for alternative energy 


\section{Response of finisher broiler birds fed graded levels of yam peel meal}

sources such that can meet the nutrient requirements of farm animals as well as being less competed for with man and industries (Akinmutimi, 2004). Yam (Dioscorea rotandata) peel is one of the various farm wastes that have such potentials (Adeyemo and Borire, 2002). Yam peel is cheaply available in Nigeria (Odoemelam, 2004). White yam peel consists of $11 \%$ crude protein with metabolizable energy of $2.604 \mathrm{Kcal} / \mathrm{g}$ (Akanno, 1998) and is rich in amino acid (Eka, 1985). Yam peels are cheaply available and not competed for by man and industries. This paper therefore highlights the potentialities of yam peel meal as a replacement for maize.

\section{Materials and methods}

The yam peels were collected from the University environment. The yam peels were sun dried, to about $10 \%$ moisture level and milled to fine particles using sieve mesh $2 \mathrm{~mm}$ in diameter and was used to formulate the test diets.

Experimental animals, diets and design One hundred and twenty (120) four weeks old unsexed Marshal Breed of broiler birds were divided into four groups of 30 birds with each of the group further replicated with 10 birds per replicate in a completely randomized design. The birds were assigned to four diets designated as $\mathrm{T}_{1}, \mathrm{~T}_{2}$, $\mathrm{T}_{3}$, and $\mathrm{T}_{4}$ containing $0 \%, 5 \%, 10 \%$ and $15 \%$ yam peel meal respectively. Feed and water were supplied ad libitum. Prior to the commencement of experiment, the birds were fed commercial broiler starter diet (yam peels free diet) for seven days to stabilize them. The birds were also given routine vaccination such as intra-ocular vaccine on the first day of life; Gumboro and Lasota Vaccine were also given on the $2^{\text {nd }}$ and $3^{\text {rd }}$ weeks of life respectively as well as other medications for good health. The litters were replaced when wet to discourage the growth of pathogens.

Table 1: Nutrient composition of the YPM based diet for finishing broilers

\begin{tabular}{lllll}
\hline Ingredients g/100g & $\mathrm{T} 1$ & $\mathrm{~T} 2$ & $\mathrm{~T} 3$ & $\mathrm{~T} 4$ \\
\hline Maize & 55.00 & 50.00 & 45.00 & 40.00 \\
Yam peel meal & 0.00 & 5.00 & 10.00 & 15.00 \\
Soya meal & 5.00 & 5.00 & 5.00 & 5.00 \\
Groundnut cake & 17.00 & 16.00 & 17.00 & 17.00 \\
Palm kernel cake & 10.00 & 10.00 & 10.00 & 10.00 \\
Fishmeal & 4.00 & 4.00 & 4.00 & 4.00 \\
Wheat offal & 4.20 & 5.20 & 4.20 & 4.20 \\
Bone meal & 4.00 & 4.00 & 4.00 & 4.00 \\
Salt & 0.30 & 0.30 & 0.30 & 0.30 \\
Vit./ trace mineral premix & 0.25 & 0.25 & 0.25 & 0.25 \\
Lysine & 0.15 & 0.15 & 0.15 & 0.15 \\
Methionine & 0.10 & 0.10 & 0.10 & 0.10 \\
Total & 100.00 & 100.00 & 100.00 & 100.00 \\
Calculated nutrient composition & & & & \\
Crude protein\% & 20.32 & 20.00 & 20.13 & 20.28 \\
Metabolizable energy Kcal/kg & 2896.54 & 2893.34 & 2889.5 & 2880.84 \\
\hline
\end{tabular}

\section{Performance determination}

The birds initial live weights were ascertained at the $4^{\text {th }}$ week and their final weights measured after 4 weeks of the experiment. Also measured were, feed intake, weight gain and feed conversion ratio (FCR).

\section{Data analysis}

Data obtained were subjected to analyses of variance using SPSS version 20. (SPSS, 


\section{Ukonu, Ohanaka, Uzegbu, Onunkwo, Oduehie, Obih and Ekenyem}

2012) and the differences between the treatment means were compared using the Duncan Multiple Range Test.

\section{Results and discussion}

Data representing the growth performance of finisher broilers fed varying levels of yam peel meal as a replacement for maize is presented in Table 2. Results obtained showed that there were no significant differences $(\mathrm{P}>0.05)$ in all the growth parameters evaluated with the exception of feed cost per kilogram. Results of this study is in line with the submissions of Akinmutimi and Onen (2008), Funmilayo and Ayodele (2010), who reported no significant effect on the growth parameters of finisher broilers even at $15 \%$ inclusion of YPM in their ration, though birds on diets T3 seem to be the least performing of all the treatment groups while the control had the highest value for most of the growth parameters recorded. The differences observed were not sufficient enough to show notable significance between the treatment mean. This is also in line with the reports of Ekenyem et al. (2006) who reported superior growth performance characteristics at 15\% YPM inclusion suggesting that YPM significantly did not depress growth / weight gain at higher inclusion levels.

Table 2: Growth performance characteristics of birds fed varying levels of yam peel meal (YPM) as a replacement for maize in finisher broilers

\begin{tabular}{llllll}
\hline Parameters & T1 & T2 & T3 & T4 & SEM \\
Initial weight $(\mathrm{g})$ & 813.33 & 770.00 & 853.33 & 793.33 & 23.29 \\
Final weight $(\mathrm{g})$ & 2189.83 & 2113.00 & 2100.48 & 2010.83 & 75.78 \\
Average daily weight gain $(\mathrm{g})$ & 49.16 & 47.96 & 44.54 & 43.48 & 3.00 \\
Feed intake $(\mathrm{g})$ & 192.02 & 182.18 & 193.94 & 197.30 & 4.46 \\
Feed conversion ratio & 3.91 & 3.98 & 4.35 & 4.53 & 0.45 \\
Cost/kg Feed & $128.35^{\mathrm{a}}$ & $123.94^{\mathrm{b}}$ & $121.65^{\mathrm{c}}$ & $118.30^{\mathrm{d}}$ & 1.10 \\
Feed cost/kg gain & 502.72 & 494.12 & 529.18 & 536.68 & 54.58 \\
\hline abcd: Means with different superscripts on the
\end{tabular}

abcd: Means with different superscripts on the same horizontal row are significantly different $(\mathbf{P}<0.05)$.

Average daily feed intake of broiler birds recorded was 192.02, 182.18, 193.94 and 197.30 for T1, T2, T3 and T4 respectively. This shows apparent increase in feed intake of the experimental diets as YPM increases. It could be suggested that a higher inclusion of YPM in the broiler ration may also increase the feed intake of the finisher broilers. This however disagrees with the findings of Funmilayo and Ayodele, (2010) who reported that the unpalatable nature of YPM may cause reduction in feed intake. Ekenyem et al. (2006) also recorded higher feed intake for broilers up to $15 \%$ level of inclusion of YPM thus suggesting that YPM improved palatability of the diets. Similarly, Ezieshi and Olomu, (2011), reported no treatment effect on the feed intake of broilers fed YPM even at a higher inclusion level of $75 \%$.
Lower feed costs were achieved with increasing levels of YPM which resulted in a considerable reduction in the cost of broiler production. Earlier reports (Ekenyem et al., 2006; Ayoola and Akinbani, 2011) also found YPM to considerably reduce the cost of broiler and rabbit production respectively.

\section{Conclusion and recommendation}

YPM could be included in broiler finisher rations up to $15 \%$ inclusion levels without deleterious effects on the performance of the broiler birds.

Inclusion of YPM in broiler finisher ration significantly reduced cost of feed consequently reducing the cost of poultry production hence makes poultry products affordable to local consumers in Nigeria.

It is therefore recommended that research 


\section{Response of finisher broiler birds fed graded levels of yam peel meal}

effort should be directed towards high inclusion levels of yam peel meal.

\section{References}

Adeyemo, A. I. and Borire, O. F. 2002. Response of giant snail (Archachatina marginata) to graded levels of yam peel meal Based diet. J. Niger. Soc. Anim. Product., pp. 14-17

Akanno, E. C. 1998. The true metabolizable energy. Nitrogen corrected true metabolized energy and true digestible protein of selected Non- conventional feeding stuffs using poultry B.Sc Project Report, Michael Okpara University of Agriculture, Umudike, pp 4-28.

Akinmutimi, A. H. 2004. Evaluation of sword bean (Canavalia gladiata) as an alternative feed resource for broiler chicken Ph.D Thesis Michael Okpara University of Agriculture, Umudike.

Akinmutimi, A. H. and Onen, G. E. 2008. The response of broiler finisher birds fed graded levels of Yam peel meal in place of maize based diets. International Journal of Poultry Science, 7(5):474-479.

Ayoola, M. A. and Akinbani, A. J. 2011. Effects of replacing maize with sundried yam peel meal on growth performance, carcass characteristics and economics of production of meat type rabbits. Research, 2(4):70 - 73.

Ekenyem, B. U., Madubuike, F. N. and Dike, O. F. 2006. Effect of partial replacement of Yam peel meal (Dioscorea spp) for maize meal Zea mays on performance and carcass characteristics of finisher broilers. International Journal of Poultry Science, 5(10): 942-945.
Ezieshi, C. V. and Olomu, J. M. 2011. Biochemical evaluations of yam peel meal for broiler chickens. Journal of agriculture and Social Research. Vol. 11.

Ezieshi, E. V., Okhueubie, I. F., Ezennabike, C. C. and Olomu, J. M. 2004. Comparative performance of broiler chicks fed graded levels of palm kernel cake and maize offal proceedings of the 29th Annual conference of NSAP. Pp. 253-256.

Funmilayo, S. M. and Ayodele, A. E. 2010. Effect of replacement of yam (Dioscorea spp) peel meal for maize (Zea mays) on growth performance, carcass characteristics and blood chemistry of finisher broilers. Journal of Agriculture and Biological Sciences Vol. 2(1) Pp. 018-021.

Obioha, F. C. 1992. A guide to poultry production in the tropics (1st ed.) Obioha, Acena public. Enugu, Nigeria. Pp 18-35.

Odoemelam, S. A. 2005. Proximate composition and selected physicochemical properties of the seeds of African oil bean (Pentaclethra marcrophylla). Pak. J. Nutr., 4: 382-383.

Ojewola, G. S. and Annah, S. I. 2006. Nutritive and Economic Value of Danish Fish Meal, Crayfish Dust Meal and Shrimp Waste Meal Inclusion in Broiler Diets. International Journal of Poultry Science, 5: 390-394.

SPSS 2012. Statistical Packages for Social Sciences, Ver. 20.0, SPSS Inc. Illinois (USA).

Received: $30^{\text {th }}$ November, 2017 Accepted: $3^{\text {rd }}$ March, 2018 